\title{
CORROSION MONITORING OF AIRCRAFT BASED ON THE CORROSION PROGNOSTIC HEALTH MANAGEMENT (CPHM) SYSTEM
}

\section{Monitorowanie korozji statku powietrznego w oparciu o system Prognostycznego Zarządzania Korozją}

\begin{abstract}
The article presents methods to monitor the actual state of aircraft's airframe, in particular, the onset of corrosion. The greatest emphasis is put on the "Corrosion Prognostic Health Management" CPHM system. Authors discuss corrosion detection using NDT methods as well as the possibilities of forecasting methods for estimating the onset of corrosion basing on the data gathered by means corrosion sensors. Based on the results of the previous research and analyses, authors focus on monitoring the internal microclimate and the factors causing corrosion in the aspect of damage tolerance operation of the aircraft. The results of the preliminary studies giving credibility to the concepts of predicting corrosion onset in the aircraft structure are presented. Preliminary results of tests carried out in supervised flights are also presented. The final part of the article presents the concept of modernizing the corrosion field site in order to use it in hermetic and non-hermetic tests of aircraft spaces.
\end{abstract}

Keywords: corrosion, aircraft, non-destructive testing

Streszczenie: $W$ artykule przedstawiono sposoby wykrywania korozji metodami NDT (głównie system Corrosion Prognostic Health Management - CPHM) oraz możliwości metod prognozowania wystapienia korozji z wykorzystaniem czujników do badań korozyjnych. Autorzy skupili się na monitorowaniu wewnętrznego mikroklimatu oraz czynników wywolujacych korozję $w$ aspekcie eksploatacji wedtug stanu statków powietrznych. Przedstawiono wyniki wstepnych badań uwiarygodniajacych koncepcje prognozowania możliwości wystapienia korozji w strukturze. Zaprezentowano również wstępne wyniki badań przeprowadzone w lotach nadzorowanych. Przedstawiono koncepcje modernizacji statych stacji korozyjnych $w$ celu ich wykorzystania wbadaniach hermetycznych oraz niehermetycznych przestrzeni statku powietrznego.

Słowa kluczowe: korozja, statki powietrzne, badania nieniszczące 


\section{Introduction}

Corrosion within airframes is a significant problem for all types of helicopters and aircrafts. Thus, it is necessary to understand the factors that control corrosion in aircrafts in order to maintain them effectively. The traditional "one size fits all" approach to maintaining aircraft is expensive, time consuming and fails us in important areas that are hard to inspect [6]. The effects of microclimates in small closed areas on atmospheric corrosion are examined for coastal conditions in all types of aircrafts. Microclimates are created by local meteorology: temperature, humidity, precipitation, wetting time, intensity and duration of solar radiation, direction and wind speed of (flow velocity), ion concentration in the air, precipitation $\mathrm{pH}$, concentration of sulphates, nitrates and chlorides in precipitation, atmospheric pressure and external polarization.

Providing the continuous airworthiness of aircraft is a huge challenge for users and maintenance organizations. To do so, various methods are used and a number of tests are carried out that allow us to determine the state of the aircraft structure. Non-destructive testing (NDT) has been used for years to detect cracks, corrosion, etc. A new trend in today's aviation is the Self Health Monitoring (SHM), which is in wider use.

To support the integrity of the aircraft structure, two aspects should be monitored. The first one is the application of the Health and Usage Monitoring System (HUMS). This system has been used for many years in fatigue of materials. The second aspect that should be monitored is environmental degradation. This is not a new trend because it was called Environmental Degradation Monitoring over Prognostics (EDMAP), but recently it has evolved to the development of microclimate sensors.

Non-destructive testing must be supported by the results of destructive tests under realreflective conditions. An example is the study of corrosion fatigue, crack growth studies and environmental degradation of joints $[10,11]$.

\section{Methods of detecting the corrosion of the aircraft structure}

Detection is a significant issue in fight against corrosion. There are many nondestructive testing methods applied to detect corrosion in the structure of aircraft. These methods allow for research without the need to interfere with the structure.

\section{a. The ultrasonic method (UT)}

All the instruments designed for corrosive applications in the ultrasonic method (UT) measure the transition time between first and back wall echo, they can also measure the interval between consecutive multiple echoes. This technique can be very useful for measuring metal thickness in detecting pits and the actual minimum material thickness. 

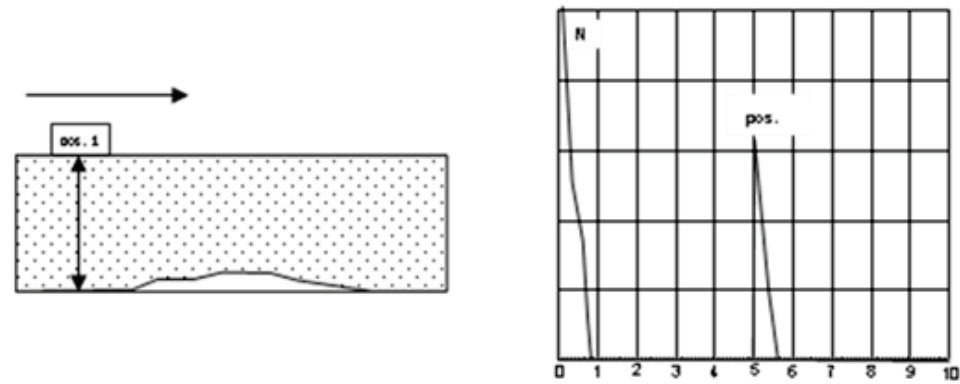

Fig. 1. Echo from the bottom
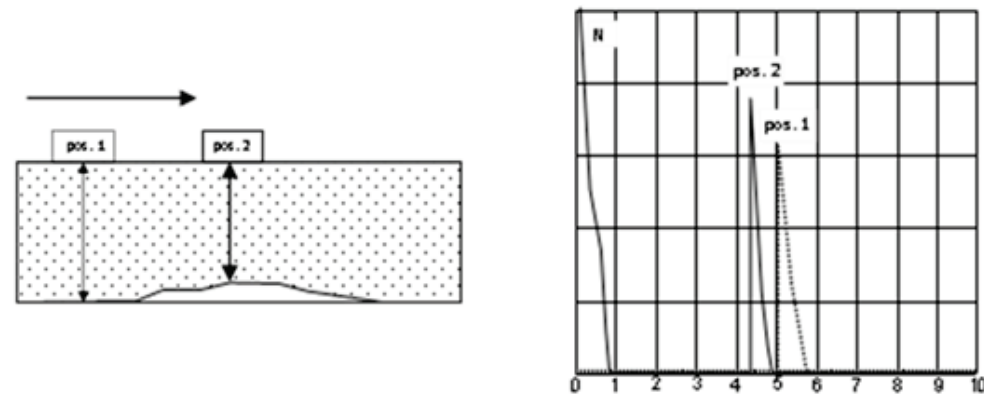

Fig. 2. Echo of damage
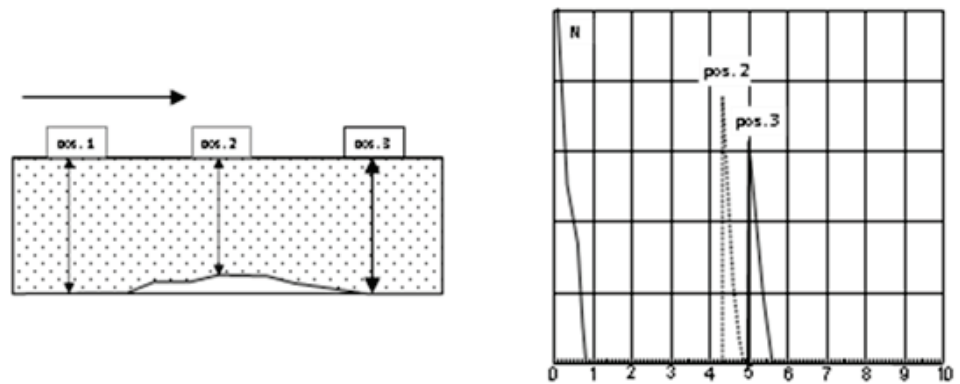

Fig. 3. Echo from the bottom

\section{b. The eddy current method (ET)}

The eddy current (ET) method is commonly used to control objects throughout their life cycle. Eddy current techniques use alternating currents applied to the conductive coil kept close to the test object. In response, the test object generates eddy currents to counteract the alternating current in the coil. Eddy currents are then detected by the same coil, separate coils or magnetic field. Exemplary indications are shown in fig. 4. 

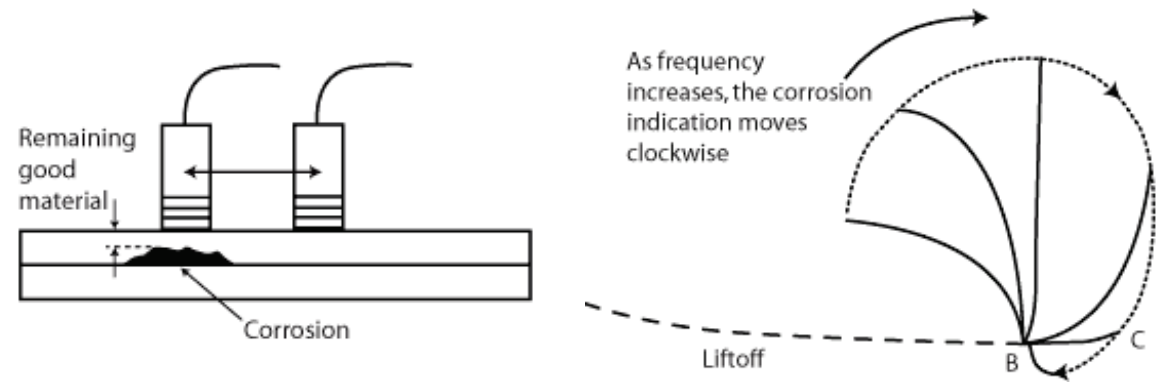

Fig. 4. Signal from corrosion in NDT (ET) [4]

\section{c. The thermography method (IRT)}

Infrared and thermal testing methods are characterized by the use of thermal measurements of a test object when it undergoes a response to a stimulus. Thermal imaging camera is the most common sensing method [5]. Hidden corrosion manifests itself mostly as a result of the material oxidation creating solid oxide compounds. In aircraft structures, because of the materials used in the plating, corrosion products are aluminium oxides. The resulting compounds are characterized by other thermal properties allowing for their detection with thermographic methods [4].

Sample lap joints
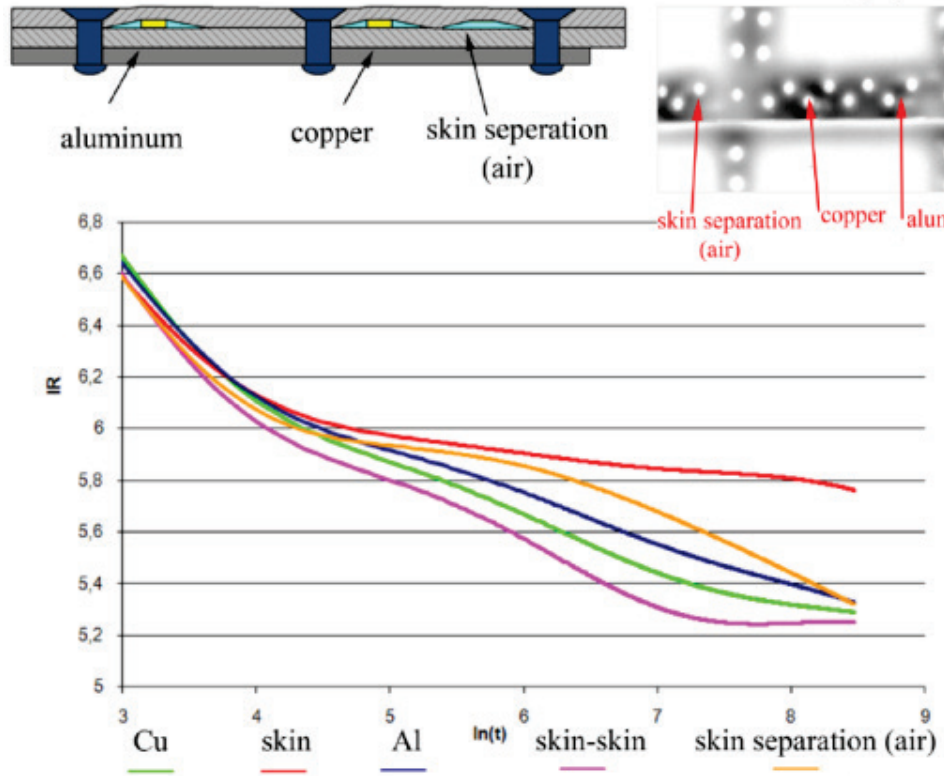

Fig. 5. Indication of the area of corrosion NDT (IRT) 


\section{d. The radiography method (RT)}

Historically, radiography is the next most common NDT method. Significant activity in the field occurred almost immediately after the Roentgen's discovery of X-rays in 1895 [2]. Early literature notes the ability of radiographs to detect discontinuities in castings, forgings, and welds in metals. Discontinuities such as pores or inclusions in metals are readily detected in many cases [5].
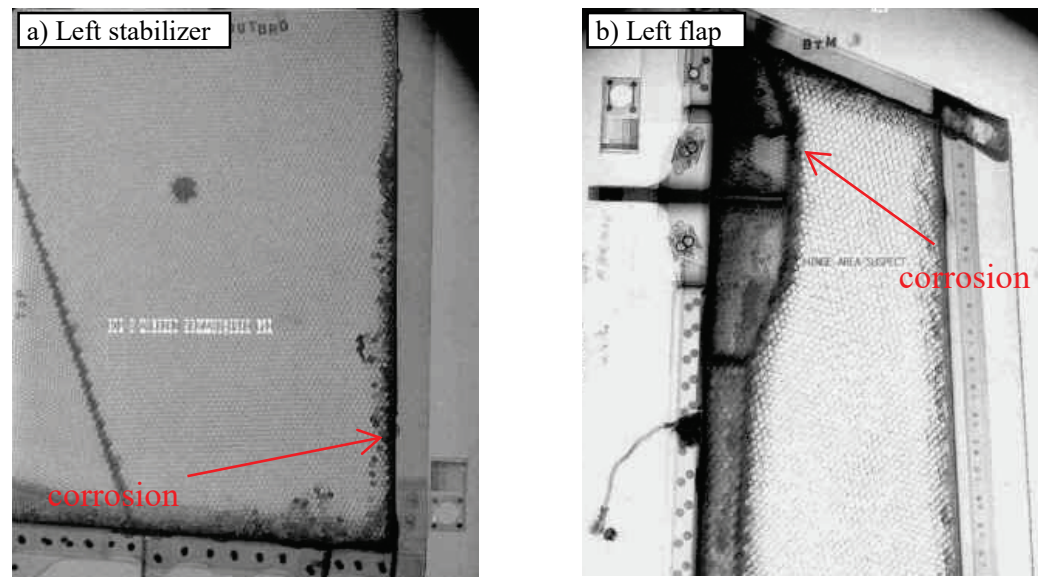

Fig. 6. Indication of the area of corrosion NDT (RT) [8]

\section{e. The D-SIGHT method}

The application of D-SlGHT to detect corrosion in lap joints is based on the observation that corrosion produces surface deformations in the aircraft skin commonly known as 'pillowing' between the fasteners of the joints. These deformations are caused by the accumulation of corrosion products between the faying (surfaces) elements of the joint [3]

Detection capability and sensitivity of D-SIGHT in comparison with other technologies was satisfactory. The method was very fast. The effects of the hidden corrosion test are presented in fig. 7.
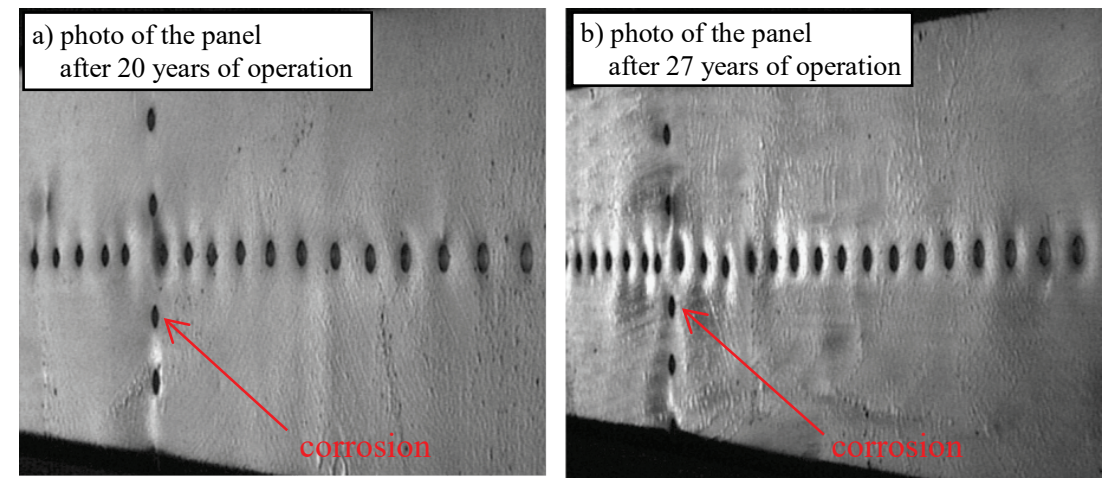

Fig. 7. Indication of the area of corrosion (system DAIS) 
The most common procedure is to inspect the fuselage joints visually from the aircraft exterior. Usually, inspectors look at the lap joint surfaces in search for traces of corrosion products, and for corrosion pillowing deformation, most often with the aid of a flashlight. Unfortunately, there is no data on the Probability Of Detection (POD) for corrosion pillowing using visual inspection [1].

\section{Several types of corrosion sensor, principally aimed at aircraft structures}

Detection of corrosion through NDT tests requires a considerable amount of resources in the form of people's work, investment in equipment and training of employees. A new trend is the system that supports non-destructive testing and signal presence of the corrosion. The systems use sensors and chemical compounds that react to the occurrence of corrosion products.

\begin{tabular}{|c|c|}
\hline SENSOR TYPE & COMMENT \\
\hline $\begin{array}{l}\text { Corrosion Coupons } \\
\text { (specimen) }\end{array}$ & $\begin{array}{l}\text { Corrosion rate is determined by weight-loss measurements. } \\
\text { Coupons can be used as reference pattern witness plates for } \\
\text { calibrating other sensors. }\end{array}$ \\
\hline Electrical Resistance & $\begin{array}{l}\text { The resistance of a metallic track is measured. Loss of metal due } \\
\text { to corrosion changes the electrical resistance. }\end{array}$ \\
\hline Galvanic & $\begin{array}{l}\text { The galvanic current or voltage generated by separated electrodes } \\
\text { made of dissimilar metals can be used to measure the presence of } \\
\text { a conducting, and hence corrosive, environment. }\end{array}$ \\
\hline $\begin{array}{l}\text { Electrochemical } \\
\text { Impedance } \\
\text { Spectroscopy (EIS) }\end{array}$ & $\begin{array}{l}\text { Electrochemical Impedance Spectroscopy (EIS) can be used to } \\
\text { assess the degradation of coatings. Portable systems are available. } \\
\text { Also, it may be possible to embed electrodes beneath the coating. } \\
\text { Such systems model the coating, substrate and electrolyte as } \\
\text { elements in an AC circuit. The resistance and capacitance of each } \\
\text { circuit element is inferred from observations of changes in } \\
\text { impedance with the frequency of a small applied potential. The } \\
\text { inferred values indicate the state of the coating. }\end{array}$ \\
\hline $\begin{array}{l}\text { Electrochemical Noise } \\
\text { (EN) }\end{array}$ & $\begin{array}{l}\text { Electrochemical Noise (EN) sensors measure the rapid } \\
\text { fluctuations in corrosion current and voltage between electrodes. } \\
\text { Corrosion potential fluctuations can indicate the onset of events } \\
\text { such as pitting, exfoliation, and stress corrosion cracking (SCC). }\end{array}$ \\
\hline
\end{tabular}




\begin{tabular}{|c|c|}
\hline SENSOR TYPE & COMMENT \\
\hline Acoustic Emission (AE) & $\begin{array}{l}\text { Laboratory tests indicate that Acoustic Emission }(\mathrm{AE}) \text { can be } \\
\text { used to monitor the propagation of corrosion and stress corrosion } \\
\text { cracking. }\end{array}$ \\
\hline Chemical sensors & $\begin{array}{l}\text { Chemical sensors measure corrosive chemical species or } \\
\text { corrosion products. There are many different technologies, } \\
\text { including Ion Selective Electrodes (ISEs), Ion-Selective Field } \\
\text { Effect Transistors (ISFETS), and optical sensors (see below). The } \\
\text { lack of long term stability and vulnerability to poisoning may } \\
\text { become a problem. }\end{array}$ \\
\hline $\begin{array}{l}\text { Corrosion-Indicating } \\
\text { Paint }\end{array}$ & $\begin{array}{l}\text { Corrosion-indicating paints are under development. The paint } \\
\text { responds to chemical changes associated with corrosion by } \\
\text { changing colour or fluorescence. Examples of relevant chemical } \\
\text { changes are, change in pH; oxidation, and complexing with metal } \\
\text { cations. }\end{array}$ \\
\hline $\mathrm{pH}$ sensors & $\begin{array}{l}\text { ISE-based } \mathrm{pH} \text { sensors are likely to be the best technology but the } \\
\text { issue of long-term calibrated performance still remains unsolved. }\end{array}$ \\
\hline Biological sensors & $\begin{array}{l}\text { Biologically-induced corrosion, or "biocorrosion", can be } \\
\text { monitored using electrochemical sensors. In general, biosensors } \\
\text { have limited lifetimes and at present are unsuitable for long term } \\
\text { exposure. }\end{array}$ \\
\hline MEMS-based sensors & $\begin{array}{l}\text { Micro-Electromechanical (MEMS) devices are usually fabricated } \\
\text { in silicon and have been proposed to be used in corrosion sensors. } \\
\text { Micro-cantilever systems whose vibration characteristics change } \\
\text { according to the mass of the beam can form the basis of a range } \\
\text { of sensors. }\end{array}$ \\
\hline Ultrasonic & $\begin{array}{l}\text { Active ultrasonic sensors comparable to those currently used in } \\
\text { NDE can measure thickness loss directly under a sensing head. } \\
\text { Guided ultrasonic waves that propagate along surfaces and } \\
\text { interfaces might detect corrosion over larger areas. SAW (Surface } \\
\text { Acoustic Wave) devices are in theory much more sensitive. }\end{array}$ \\
\hline Optical sensors & $\begin{array}{l}\text { An optical fibre with Bragg gratings can be coated with an } \\
\text { electrochemically active species that changes colour as a result of } \\
\text { the corrosion reaction. These sensors can be embedded in sealant } \\
\text { and can monitor long lengths of structure. The lack of long term } \\
\text { stability and vulnerability to poisoning may become a } \\
\text { problem.[7] }\end{array}$ \\
\hline
\end{tabular}




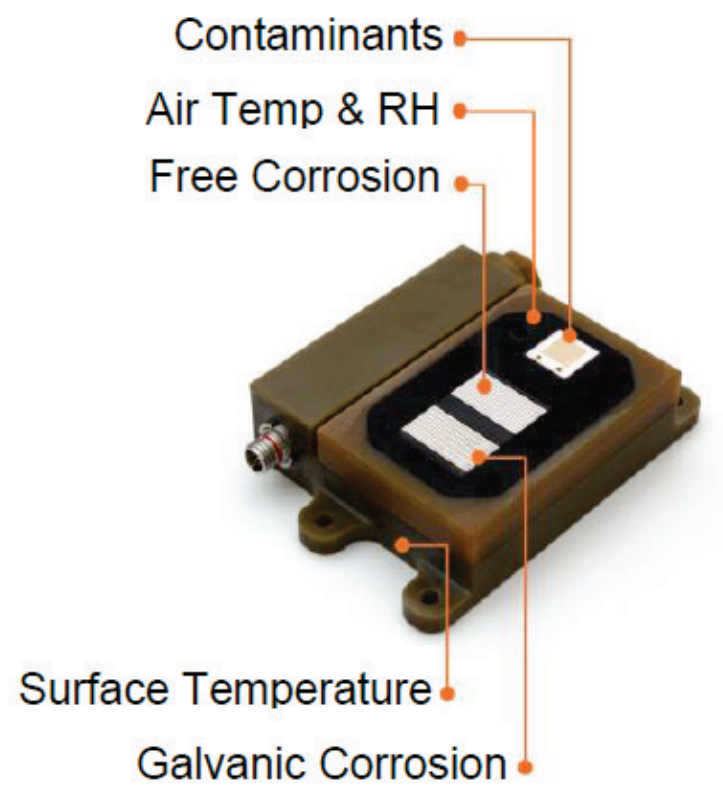

Fig. 8. A group of corrosion and microclimate sensors from LUNA Incorporation - Acuity LS

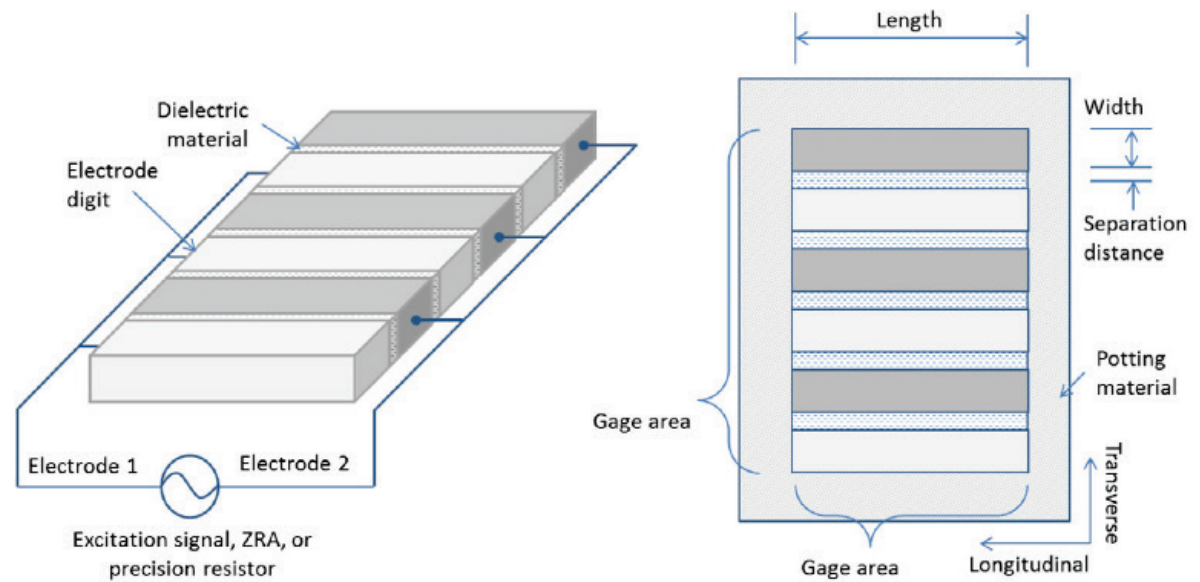

Fig. 9. Schematic Isometric and Top View of Laminated Interdigitated Two-Electrode Sensor 


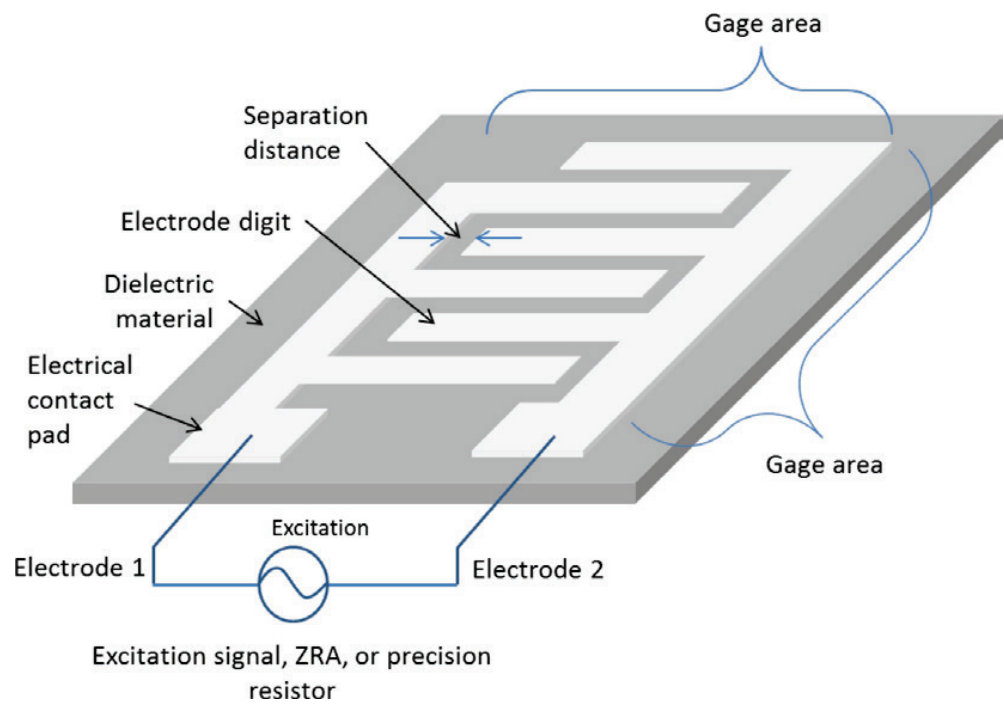

Fig. 10. Schematic of Laminated Thin Film Interdigitated Two-Electrode Sensor

\section{Microclimate tests in the aspect of corrosion detection}

Climate conditions in closed spaces in relation to weather conditions can be dramatically different. The structure of a helicopter operating in a base is subject to continuous degradation due to environmental conditions. Weather changes depending on the time of a day, season and conditions prevailing at the airport. Anticorrosive protection means of a helicopter are often closely related with weather conditions, e.g. marine helicopters operated on aircraft carriers are more exposed to atmospheric conditions than helicopters used on a desert, e.g. in Afghanistan.

Similar differences can be observed in the case of climatic differences prevailing in the open space and closed spaces, e.g. in the interior of the tail beam. Also, atmospheric conditions can change dramatically during the flight, which has a huge impact on the conditions prevailing in confined spaces.

\section{Preliminary results of corrosion tests carried out in supervised flights}

The first sets of data obtained from corrosion sensors in the aspect of the microclimate of closed spaces on aircraft allowed for the first approximate iteration of results. Figure 11 shows the preliminary alternative to approximating the results. The graph presents the analysis of acquired data from corrosion sensors placed on the aircraft, which performed 
flights in spring and summer (the presented period lasts only a few days). The obtained records allow us to interpret preliminary data and show different circumstances of flights.

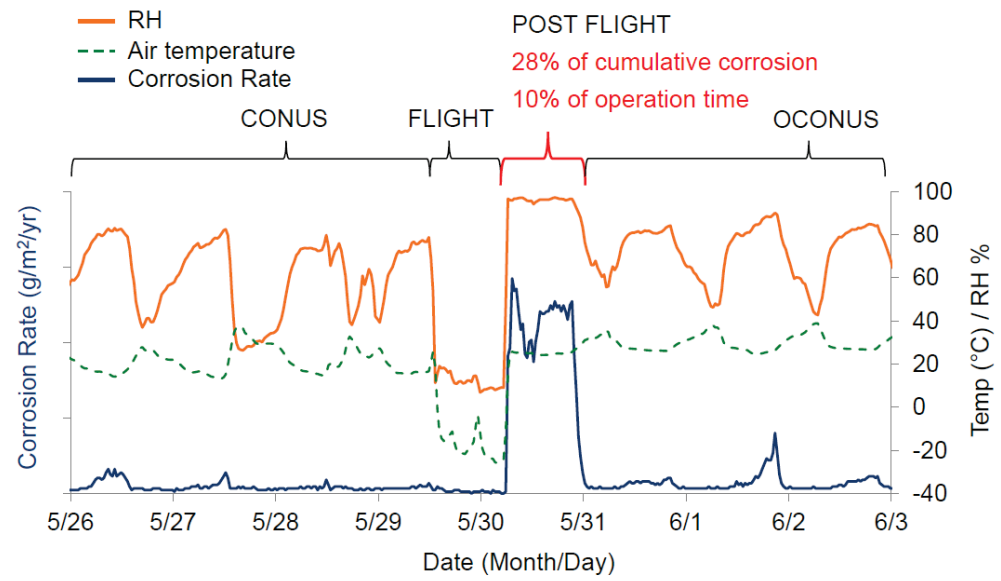

Fig. 11. Preliminary results of corrosion tests carried out in supervised flights (property of LUNA Incorporation)

\section{The concept of a corrosion field site}

The concept of using corrosion field site is to collect data from sensors placed in closed spaces located at permanent corrosion stations. Corrosion field site are supposed to imitate the structure of the aircraft, in which corrosive sensors and samples will be placed. Part of the samples are typical corrosion samples without varnish coating. Some of these will be covered with an anode, the next set of samples will be covered with an anode and a coating layer corresponding to the coating on aircraft and the subsequent set of samples will be protected with an anode, lacquer and temporary protection Dinitrol AV30. The entire set of samples reflects the situation by collecting data, analyzing them and comparing them with the data obtained. They will allow for the verification of data derived from sensors placed in closed spaces on the aircraft. Consequently, it will be possible to compare the weather conditions prevailing at the corrosion stations with the microclimate conditions prevailing in the confined spaces of the helicopter during flight. The dates should confirm the results based on the corrosion present on samples with a corrosive atmosphere of the microclimate.

Corrosion sensors installed on the helicopter structure in fig. 12 will enable us to collect data on the microclimate prevailing in the closed spaces of the structure. The flight recorder will allow us to collect data of flight parameters such as altitude, climb speed, time spent at a given altitude, etc. Data from meteorological stations will indicate the conditions prevailing outside the aircraft. Data from corrosion field site will determine the degree of corrosion degradation of materials subjected to testing. 


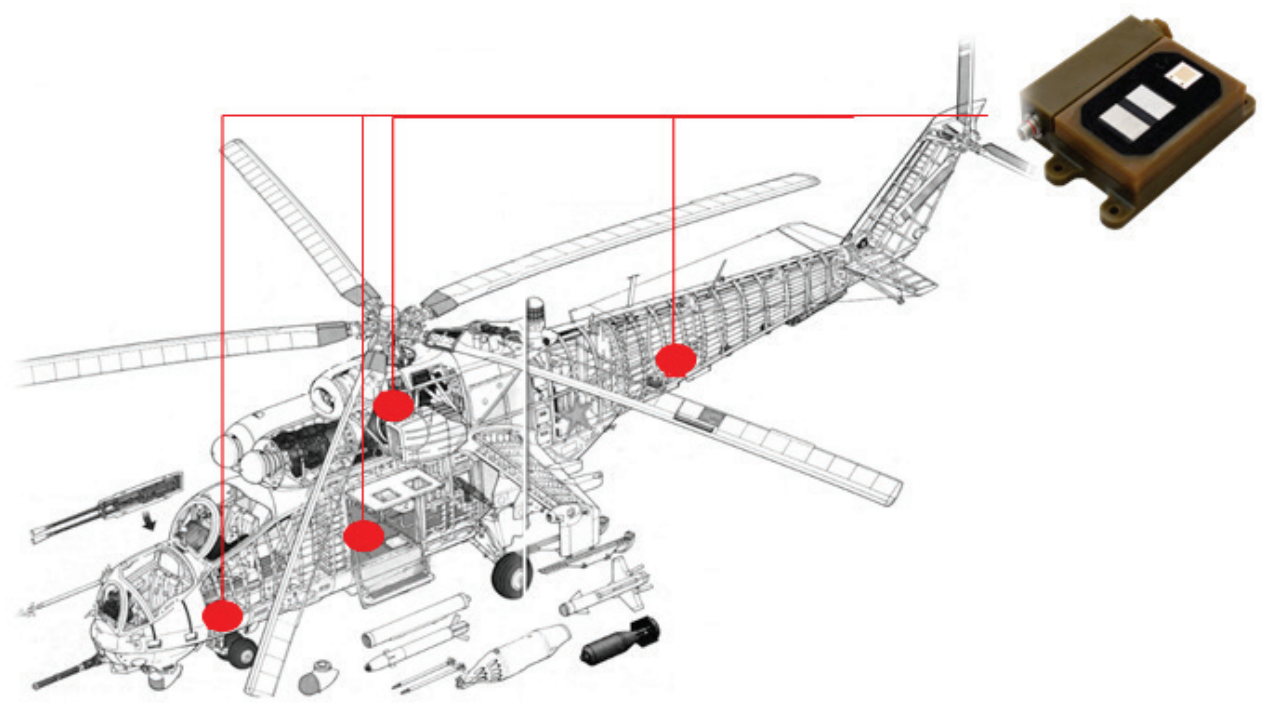

Fig. 12. Corrosion Prognostic Health Management (CPHM) system

The comparison of all data and their full analysis will enable for the development of a system that allows for signaling the occurrence of corrosion and even forecasting the occurrence of corrosive conditions.

\section{Conclusions}

The aircraft that retired due to fatigue could probably be used for more decades, but we can't accurately predict the exact failure point. A CPHM system employs the same philosophy with corrosion - with the appropriate safety margins and conservative assumptions in its models, it can give an early indication of when the corrosion might commence. Corrosion inspections are therefore unnecessary until that point. The CPHM system over the last years was called Environmental Degradation Monitoring and Prognostics (EDMAP).

The integrity of the aircraft structure is a necessary condition to safely complete the tasks for which the aircraft has been designed. The violation of the structure integrity is understood as a crack, a tear or a break of a construction fragment. Providing the integrity of the structure is a first priority activity throughout the aircraft lifetime. The inability to ensure the structure integration is a factor that has an impact on the aircraft's immediate withdrawal from operation. In the final period of helicopter operation, there are some problems related to providing the structure integrity. This is caused by the accumulation of fatigue loads in the structure - further intensified by the corrosion of the material. 
The activities undertaken so far are of a preventive nature and do not offer a comprehensive solution to these problems. The corrosion damage, resulting from aircraft operation, should be detected and removed in a timely manner. Corrosion centres that are not removed will be spreading incessantly. The development and the course of corrosive processes are influenced by internal and external factors. Internal factors include metal type, chemical composition, structure, surface condition, heat treatment, mechanical treatment and own stresses. External factors contain temperature, humidity, amount of rainfall, wetting time, intensity and duration of solar radiation, direction and speed of winds (flow velocity), ion concentration in the air, precipitation $\mathrm{pH}$, sulphates, nitrates and chlorides concentration in precipitation, atmospheric pressure, external polarization.

\section{References}

1. Bellinger N.C.: Chapter 7 - Corrosion morphology: corrosion pillowing and cracking

2. Bossi R.H., Iddings F.A., Wheeler G.C., Moore P.O.: Radiographic Testing, Nondestructive Testing Handbook. American Society for Nondestructive Testing, Columbus, 3rd. ed., vol. 4, USA 2002.

3. DOF/FAA/AR-95/15, Development of a D SIGHT Aircraft Inspection System: Phase 11, March 1996, Final Report.

4. Dragan K., Kornas Ł.: Analysis of the Possibility to Assess the Occurrence of Hidden Corrosion in Lap Joints Using Active Thermography, 2011.

5. Forsyth D.S.: Chapter 21 - Non-destructive testing for corrosion, Texas Research International, Austin, Texas, USA 2012.

6. Ganthera W.D., Patersona D.A., Lewisb C., Isaacsb P., Galeac S., Meunierd C., Mangeond G., Colea I.S.: Monitoring Aircraft Microclimate and Corrosion. 6th Asia Pacific Workshop on Structural Health Monitoring, Procedia Engineering, vol. 188, 2017.

7. Harris S.J., Hebbron M, Mishon M.: Corrosion Sensors to Reduce Aircraft Maintenance. RTO AVT-144 Workshop on Enhanced Air-craft Platform Availability Through Advanced Mainte-nance Concepts and Technologies, Vilnius 2006.

8. https://www.olympus-ims.com/en/applications/corrosion-detection-eddy-current/ OLYMPUS.

9. Lewis W.J., Bennett L.G.I.: The use of Neutron Radiography in the Inspection of Aircraft Composite Flight Control Surfaces. Department of Chemistry and Chemical Engineering Royal Military College of Canada, Canada 1999.

10. Mathew N.M., Vishnuvardhan S., Raghava G., Santhi A.S.: Corrosion Fatigue Crack Growth Studies on Pressure Vessel and Piping Steels in Water Environment. Archives of Metallurgy and Materials, vol. 62, iss. 3, 2017.

11. Topolska S., Łabanowski J.: Environmental Degradation of Dissimilar Austenitic 316L and Duplex 2205 Stainless Steels Welded Joints. Archives of Metallurgy and Materials, vol. 62, iss. 4, 2017. 